Article

\title{
The Stabilization of Liquid Smoke through Hydrodeoxygenation Over Nickel Catalyst Loaded on Sarulla Natural Zeolite
}

\author{
Saharman Gea ${ }^{1, *} \mathbb{0}$, Agus Haryono ${ }^{2}$, Andriayani Andriayani ${ }^{1}$, Junifa Layla Sihombing ${ }^{3}$, \\ Ahmad Nasir Pulungan ${ }^{3}$, Tiamina Nasution ${ }^{3}$, Rahayu Rahayu ${ }^{3}$ and Yasir Arafat Hutapea ${ }^{1}$ \\ 1 Department of Chemistry, Faculty of Mathematics and Natural Sciences, Universitas Sumatera Utara, Jl. \\ Bioteknologi No. 1, Medan 20155, Indonesia; andriayani@usu.ac.id (A.A.); \\ arafatyasir195@gmail.com (Y.A.H.) \\ 2 Research Centre for Chemistry, Indonesian Institute of Sciences, Kompleks Puspitek 452, Serpong, \\ Tangerang Selatan, Banten 15314, Indonesia; agus.haryono@lipi.go.id \\ 3 Department of Chemistry, Faculty of Mathematics and Natural Sciences, Universitas Negeri Medan, Jl. \\ Willem Iskandar Pasar V Medan Estate, Medan 20221, Indonesia; junifalaylasihombing@unimed.ac.id (J.L.S.); \\ nasirpl@unimed.ac.id (A.N.P.); minahtia12@gmail.com (T.N.); ayurah365@gmail.com (R.R.) \\ * Correspondence: s.gea@usu.ac.id
}

Received: 3 May 2020; Accepted: 8 June 2020; Published: 16 June 2020

\begin{abstract}
Constituents of liquid smoke possess a huge potential to be converted as value-added chemicals, such as flavoring, antiseptics, antioxidants, or even fossil oil substitutes. However, liquid smoke instability, led by the presence of oxygenate compounds, is an obstacle for further utilization and processing. On the other hand, catalyst efficiency in hydrodeoxygenation (HDO) remains challenging. Sarulla natural zeolite (Z), with abundant availability, has not been comprehensively investigated in the catalytic performance of HDO. In this study, Sarulla natural zeolite with different $\mathrm{Si} / \mathrm{Al}$ ratios, which are activated by several concentrations of hydrochloric acid and nickel supported by $\mathrm{Z}$ (Ni-Z) synthesized by wet impregnation, were evaluated for HDO of liquid smoke, particularly in reducing oxygenate compounds. Catalyst morphology, surface area, pores, and crystallinity are investigated. Catalytic performances were evaluated, particularly on reducing oxygenate compounds and the shifting of phenol and its derivatives. Furthermore, the liquid smoke product of HDO was analyzed by gas chromatography-mass spectrometry (GC-MS). The data obtained reveal that the HDO process of liquid smoke with the Z3 catalyst shows the best activity compared to Z5 and Z7, with phenol conversion of $62.39 \%$ and $11.93 \%$ of alkoxy reduction. Meanwhile, the best Ni metal catalyst system activity was given by the Ni-Z5 catalyst compared to Ni-Z3 and Ni-Z7, where phenol conversion and alkoxy reduction were at $60.06 \%$ and $11.49 \%$, respectively.
\end{abstract}

Keywords: liquid smoke; phenols; hydrodeoxygenation; catalyst; natural zeolite

\section{Introduction}

Liquid smoke as a result of pyrolysis of lignocellulosic biomass has driven research attention because of its constituents' potential as a substitute for fossil fuel, flavorings, colorings, antiseptics, and antioxidants and other value-added chemicals. Hasanah et al. [1] reported liquid smoke obtained from coconut shells consists of phenol (16.4\%), hydrocarbon (12.4\%), phenolic (27.6\%), and oxygenate compounds (53.6\%), and acetic acid (3\%). Hadanu et al. [2] identified volatile compounds of coconut shell liquid smoke based on the percentage composition of each functional group as follows: phenol $(90.75 \%)$, carbonyl $(3.71 \%)$, alcohol $(1.81 \%)$, and benzene $(3.73 \%)$. However, the presence of reactive oxygenates and heavy molecular compounds leads to the instability of liquid smoke. Polymerization 
and condensation reactions occur during its storage and accelerate easily by temperature increase or oxidation. The instability of liquid smoke generates difficulties in further processing, such as constituent separation or conversion.

Hydrodeoxygenation (HDO) is a promising process to remove oxygen that binds to hydrocarbons [3,4] through hydrodeoxygenation (removal of C-O), hydrogenation (saturation of $\mathrm{C}=\mathrm{O}$ and aromatic rings), hydrogenolysis, and hydrocracking [5]. Moreover, HDO produces more stable hydrocarbons with higher energy content [6,7]. Ly et al. [8] reported that HDO of Saccharina japonica algae oil reduced the oxygen constituent, then improved the C/O molar ratio, which would be a benefit, resulting a higher heating value (HHV). In addition, Schmitt et al. [9] reported the HDO of beech wood pyrolysis oil showed more than $50 \%$ oxygen and $80 \%$ water removed.

Among the oxygen removal techniques, catalyzed HDO is believed to be the most efficient [10]. Zeolite has been developed as catalysts for HDO [10-14] due to their attractive characteristics, such as being hydrophobic, large size of pores, and being thermally stable $[15,16]$. A bifunctional catalyst such as metal-zeolite, which has active metal centers and acid sites of zeolite and synergetic function in hydrogenation and deoxygenation. Considering its low cost and availability, nickel is more attractive. Furthermore, nickel has been used as support towards its catalytic performance. Rahayu et al. [17] stated that $\mathrm{Ni}$ load on zeolite has 12 times higher acidity and increases the crystalline degree by $7.40 \%$ compared to activated zeolite without metals. This catalyst increases the yield of bio-oil by $40.38 \%$ compared to natural zeolite.

A bifunctional system has been reported to have significant effects towards the reaction routes to increase phenolic conversion [18]. Yu et al. [19] reported a bifunctional catalyst, $\mathrm{Ni}_{3} \mathrm{P} / \mathrm{HZSM}-5$, that has hydrogenation sites and acid sites, showing the highest catalytic performance in the HDO of phenols to cycloalkanes. On the other side, based on the report by Prihatini et al. [20], the addition of Ni metal to the oxide support decreases the surface area, the volume of mesopores, and the diameter of micropores, while mesopore diameter increases in contrast. HDO from the mixture of furfurilidene acetone (Fac) compounds and difurfurilidene acetone $\left(\mathrm{F}_{2} \mathrm{Ac}\right)$ compounds produces $100 \%$ product conversion with a selectivity of 8 -octanol and 6-dodecene as $88.22 \%$ and $2.99 \%$, respectively.

Sarulla natural zeolite is considered as a potential catalyst in terms of its abundance and characteristics. It was reported that Sarulla natural zeolites contain mordenite and clinoptilolite minerals as mesoporous materials. Moreover, they possess high surface area and thermal stability after the activation and calcination treatment [21]. Currently, Sarulla natural zeolite has not been comprehensively evaluated as an HDO catalyst for liquid smoke stabilization. Therefore, this research aims to develop Sarulla natural zeolites as a catalyst with different $\mathrm{Si} / \mathrm{Al}$ ratios along with Ni-loaded on zeolites. The variation in the treatment of Sarulla natural zeolite preparations is intended to find the most appropriate treatment that can obtain a catalyst with the best properties, able to convert the most oxygenate compounds into phenols and their derivatives. Its performance would then be investigated in oxygen containers, removing and expecting the stabilization of liquid smoke for a certain storage duration. The process itself was carried out at low temperatures and atmospheric pressure, with low-cost and environmentally friendly processes.

\section{Materials and Method}

\subsection{Materials}

Natural zeolite was obtained from Sarulla Pahae Jae Village, North Tapanuli, North Sumatera, Indonesia. Liquid smoke was obtained from the local producer of charcoal as the byproduct of coconut shell pyrolysis. $\mathrm{HCl}$ p.a. grade 37\% were purchased from Merck (Darmstadt, Germany). Precursor metal of $\mathrm{Ni}\left(\mathrm{NO}_{3}\right) \cdot 6 \mathrm{H}_{2} \mathrm{O}$ was purchased from Merck (Kenilworth, $\mathrm{NJ}$, USA), and distilled water was purchased from Bratachem (Jakarta, Indonesia). Lastly, hydrogen, oxygen, and nitrogen gases were purchased from PT. Aneka Gas (Medan, Indonesia). All the chemicals used in this work were used 
without further purification. The HDO experiment was supported by a reflux apparatus, Buchner funnels, vacuum pumps, a hotplate stirrer, magnetic stirrers, and a reactor for the HDO process.

\subsection{Preparation and Activation of Sarulla Natural Zeolite}

The preparation of natural zeolite refers to the study of Sihombing et al. [15]. However, in this study, natural zeolite activation was performed with several concentrations of hydrochloride acid: 3, 5, and $7 \mathrm{~mol} / \mathrm{L}$. Firstly, Sarulla natural zeolite was grounded and sifted to obtain 100 mesh of size. Then, natural zeolite was soaked in distilled water for $24 \mathrm{~h}$ at room temperature, then filtered. The obtained precipitation was dried at $110{ }^{\circ} \mathrm{C}$ and then calcined to get clean natural zeolite (Z). Natural zeolite was activated with $100 \mathrm{~mL} \mathrm{HCl}$ with various concentrations of 3,5 , and $7 \mathrm{~mol} / \mathrm{L}$. The mixtures were refluxed at $90^{\circ} \mathrm{C}$ for $2 \mathrm{~h}$, then filtered and washed with distilled water until the neutral $\mathrm{pH}$ was reached. These zeolites were then dried and recalcined with nitrogen gas flow for $2 \mathrm{~h}$ at $500{ }^{\circ} \mathrm{C}$ to obtain $\mathrm{Z} 3, \mathrm{Z}$, and $\mathrm{ZZ}$ as natural zeolite catalysts.

$\mathrm{Ni}$ loading on each $\mathrm{Z}$ was done by the wet impregnation method, following previous research [15]. As much as $100 \mathrm{~g}$ of $\mathrm{Z}$ was mixed with $1.6070 \mathrm{~g}$ of water purified dissolved $\mathrm{Ni}\left(\mathrm{NO}_{3}\right)_{2} \cdot 6 \mathrm{H}_{2} \mathrm{O}$. This mixture was refluxed and stirred by a magnetic stirrer at $80^{\circ} \mathrm{C}$ for $5 \mathrm{~h}$, then put in an oven for drying and followed by a calcination process at $500^{\circ} \mathrm{C}$ for $2 \mathrm{~h}$ with $\mathrm{N}_{2}$ gas flow $( \pm 5 \mathrm{~mL} / \mathrm{s})$. The resulted material was then oxidized and reduced at $500{ }^{\circ} \mathrm{C}$ for $2 \mathrm{~h}$, respectively, with $\mathrm{O}_{2}$ and hydrogen gas flow $( \pm 5 \mathrm{~mL} / \mathrm{s})$ to obtain Ni-Z3, Ni-Z5, and Ni-Z7 catalysts.

\subsection{Characterization of Catalysts}

Several significant properties of Ni-Z3, Ni-Z5, and Ni-Z7 catalysts were characterized by X-ray diffractometer (XRD) Shimadzu 6100 (Kyoto, Japan). The crystallinity and crystallite size were observed by XRD analysis methods using $\mathrm{Cu}$ Ka radiation at $40 \mathrm{Kv}$ and $30 \mathrm{~mA}$, with a scanning rate of $2^{\circ} \mathrm{min}^{-1}$ in the range of $2 \theta$ of $7^{\circ}-70^{\circ}$. Furthermore, catalyst surface morphology was observed with scanning electron microscope and energy-dispersive $x$-ray spectroscopy (SEM-EDX) analysis methods, using Zeis type EPOMH 10Zss (Carl series Group, Oberkochen, Germany) and SEM type JSM-6510LA, with SEM-EDX dan SEM-mapping. SEM-EDX and SEM mapping were used to analyze the composition, surface topology, and metal scattering. Lastly, surface area, total pore volume, and pore diameter were measured with the BET method using a Quantachrome NOVA 1200e gas sorption analyzer (Boynton Beach, FL, USA).

\subsection{Liquid Smoke Preparation}

Liquid smoke was prepared, following the procedure by Sari et al. [22], and was purified by a multilevel distillation method. As much as $400-500 \mathrm{~kg}$ of coconut shells were inserted into the reactor while the wood-burning process in a rocket stove was conducted. The drying process was assisted by a blower to accelerate the evaporation of the moisture content included in the coconut shell. After the smoke was observed and the released smoke was no longer concentrated, it was clearer, and then all the smoke pipes were closed. Finally, the reactor door remained closed and the smoke pipe was opened to speed up the cooling process. The resulting liquid smoke was then analyzed with GC-MS (gas chromatography-mass spectrometry) QP2010 Ultra Shimadzu.

\subsection{Liquid Smoke Hydrodeoxygenation (HDO) Process}

The process of HDO was carried out using the Z3, Z5, Z7, as well as Ni-Z3, Ni-Z5, and Ni-Z7 catalysts with a ratio of $1 \%(w / w)$. Liquid smoke and catalyst were inserted into a reactor and heated at $90{ }^{\circ} \mathrm{C}$ with an $\mathrm{H}_{2}$ gas flow of $10 \mathrm{~mL} /$ minute for $5 \mathrm{~h}$. Liquid smoke of the $\mathrm{HDO}$ product was characterized by using GC-MS to determine the compound composition shifting. Water content, density, and acidity were also evaluated. The HDO process scheme is described in Figure 1 below. 


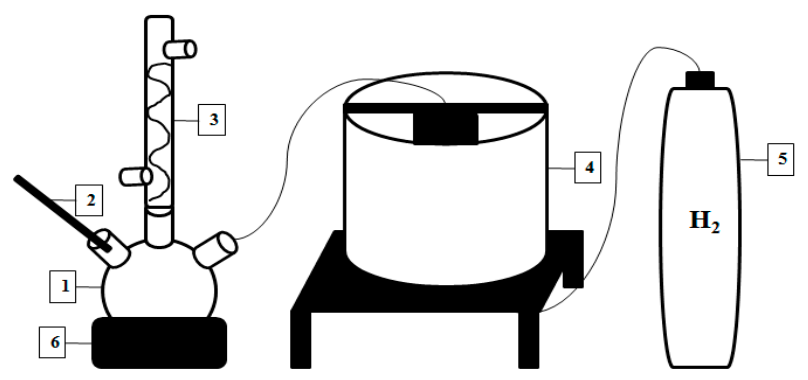

Figure 1. Hydrodeoxygenation (HDO) process scheme. Note: (1) sample bottom flask; (2) thermometer; (3) condenser; (4) reactor; (5) hydrogen gas tank; (6) heater.

\section{Result and Discussion}

\subsection{Catalyst Morphology}

SEM analysis was conducted to determine the changes in zeolite surface topology due to acid activation treatment. The results of SEM photographs, with 1000 times magnification for each catalyst, are presented in Figure 2. Figure 2a shows the surface topology of $Z$ without the acid activation treatment, indicating an irregular grain shape. The $\mathrm{Z}$ surface morphology looks heterogeneous, and a contaminant seems to cover the pores. In particular, the comparison of zeolite surface topology after acid activation is given in Figure $2 b-d$. In Figure $2 b, \mathrm{Z} 3$ produces a more uniform surface topology, and the presence of granules tends to be cubic, while in Figure $2 c, d$, the catalysts $Z 5$ and $Z 7$ show a more uniform surface topology, with finer grains, and tend to be flat or slab. To conclude, increasing acid concentration will give more uniform morphology as the activation with $\mathrm{HCl}$ can remove both crystalline and amorphous impurities that cover the zeolite pores.

Acid activation and calcination treatments indicate the formation of smaller grain, as well as giving a uniform surface of zeolite. Prasetyo et al. [23] have reported that Malang natural zeolite that has undergone a dealumination and calcination process showed smaller grain and uniform morphology. However, there is no confirmation of zeolite structure changes. The same result was reported by Sihombing et al. [21], describing that surface morphology of the Sarulla natural zeolite after the activation and calcination process became finer and more uniform.

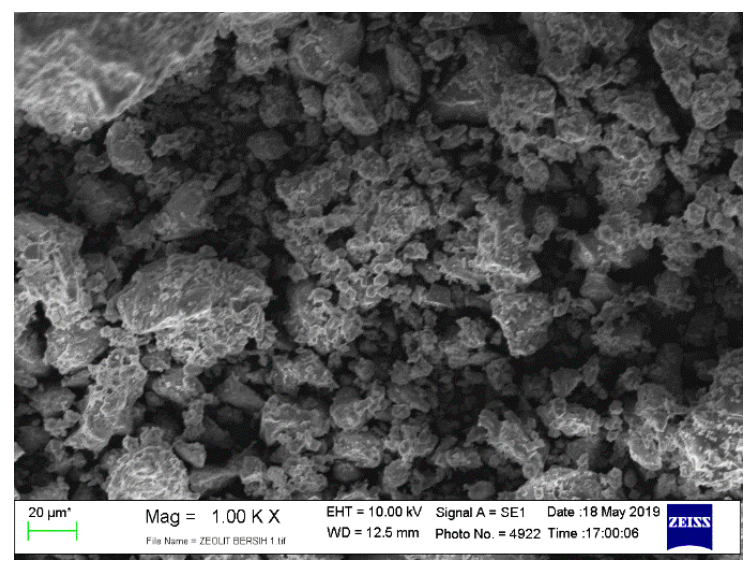

(a)

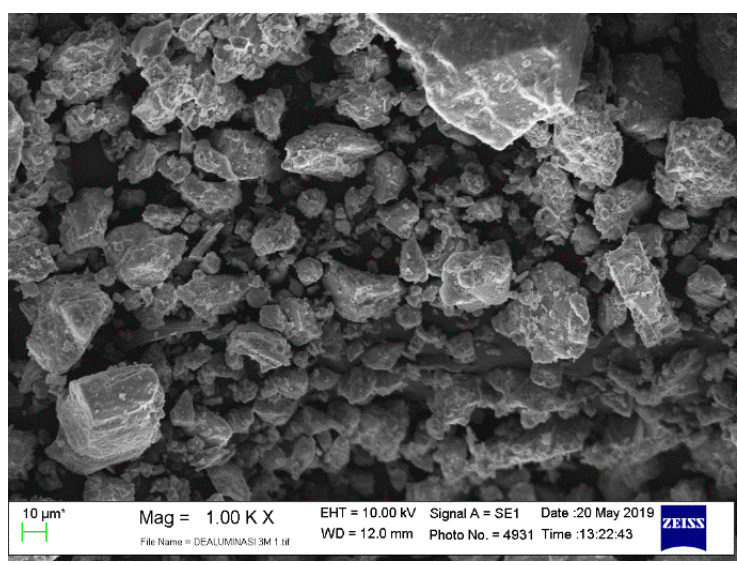

(b)

Figure 2. Cont. 


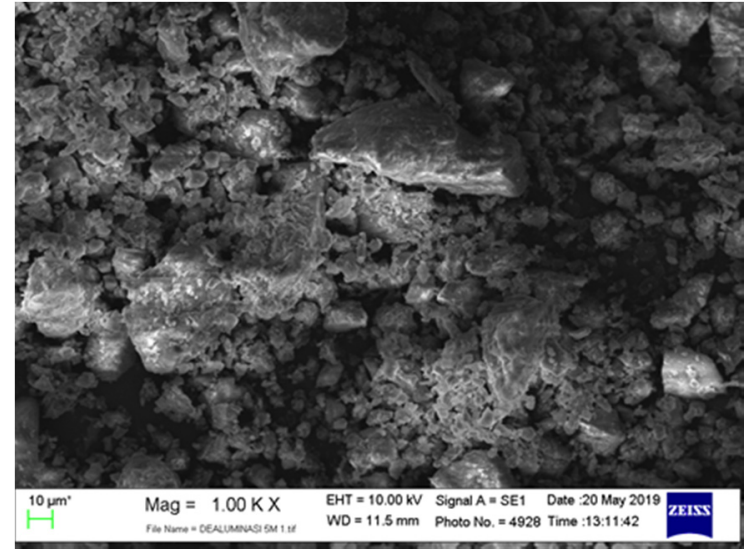

(c)

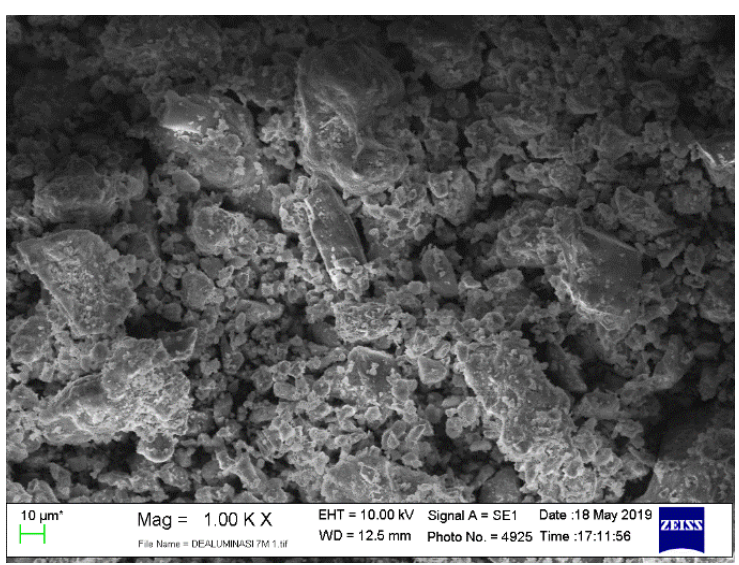

(d)

Figure 2. SEM morphology at 100 times magnification for catalysts of (a) Z, (b) Z3, (c) Z5, and (d) Z7.

Chemical compositions of Sarulla natural zeolite were also observed (Table 1). Based on Table 1, the main components of Sarulla natural zeolite $(\mathrm{Z})$ were found to be $\mathrm{O}, \mathrm{Si}, \mathrm{Mg}$, and $\mathrm{Al}$. After dealumination, Si content increased by $70 \%$, while $\mathrm{Al}$ content decreased by $30 \%$. This indicates that the use of acid was able to increase $\mathrm{Si}$ and remove the impurities that cover the surface and pore zeolites, resulting in a more porous and homogeneous morphology. The acid activation and calcination allow carbon deposition to occur during the acid activation process, and the acid density used influences the content of carbon formed. This is possible since the natural zeolite raw material already contains carbon as an organic impurity, both crystalline and amorphous, that exists on the surface of the pores, or trapped inside the pores, even though in very small amounts. The activation of acid causes most of these impurities to emerge from the opening of the pores and allows the formation of carbon deposits during the process. The same results have also been reported by Sentosa et al. [24], where EDS data show Bayah natural zeolite has a carbon level of $13.83 \%$, which even increases after the activation process with $\mathrm{HCl}$ acid to $30-36 \%$.

Table 1. Catalyst chemical compositions based on scanning electron microscope and energy-dispersive x-ray spectroscopy (SEM-EDX) data.

\begin{tabular}{ccccc}
\hline \multirow{2}{*}{ Elements } & \multicolumn{4}{c}{ Mass (\%) } \\
\cline { 2 - 5 } & $\mathbf{Z}$ & $\mathbf{Z 3}$ & $\mathbf{Z 5}$ & $\mathbf{Z 7}$ \\
\hline $\mathrm{C}$ & - & 23.25 & 2.68 & 20.27 \\
$\mathrm{O}$ & 61.58 & 49.08 & 60.81 & 71.01 \\
$\mathrm{Si}$ & 15.73 & 23.72 & 25.35 & 23.74 \\
$\mathrm{Al}$ & 5.64 & 3.45 & 0.90 & 3.79 \\
$\mathrm{~K}$ & 3.16 & - & - & 0.98 \\
$\mathrm{Fe}$ & 4.60 & - & - & - \\
$\mathrm{F}$ & - & - & 1.28 & - \\
$\mathrm{Ca}$ & - & 0.50 & 4.52 & - \\
$\mathrm{Mg}$ & 7.93 & - & 4.47 & - \\
$\mathrm{Ti}$ & 1.37 & - & - & - \\
$\mathrm{Hg}$ & - & - & - & 0.48 \\
\hline
\end{tabular}

Based on the surface morphology of nickel loaded on the zeolite catalyst (Figure 3), the crystal size change is more homogenous, indicating the absence of a sintering process. The distribution of $\mathrm{Ni}$ metal dispersed on the surface of the catalyst, analyzed by SEM-mapping, is described in Figure 4. 

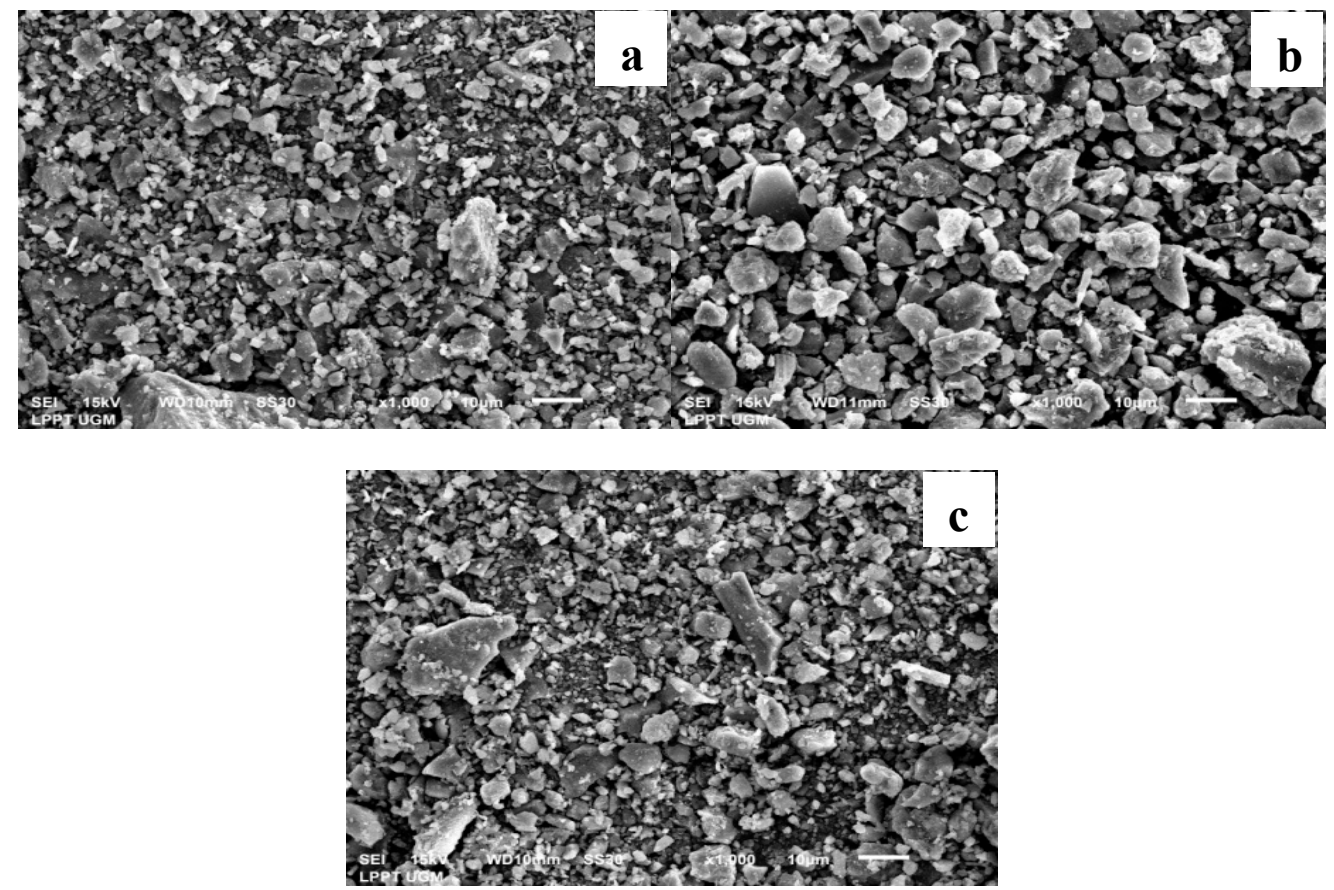

Figure 3. Catalyst surface morphology at 1000× magnification of (a) Ni-Z3, (b) Ni-Z5, and(c) Ni-Z7.

The results of SEM-mapping surface images of the Ni-Z3, Ni-Z5, and Ni-Z7 catalysts in Figure 4 show that the $\mathrm{Ni}$ is homogeneously distributed on the $Z$ carrier surface. There are no significant differences among metal distribution on $\mathrm{Ni}-\mathrm{Z3}, \mathrm{Ni}-\mathrm{Z} 5$, and Ni-Z7 catalysts. $\mathrm{Si}$ and $\mathrm{Al}$ are observed to be the main components of catalysts. These components are distributed in the same areas and they form chunks that indicate zeolite existence. Moreover, Ni metal mapping shows that $\mathrm{Ni}$ is spread evenly in all areas rather than just being concentrated in one certain place. With this result, Ni metal has successfully been exchanged and impregnated in the catalyst structure or surface. Meanwhile, to confirm the loading of nickel onto the $\mathrm{Z}$ catalysts, the EDS test was conducted, the results of which can be seen in Table 2. Based on Table 2, the amount of Ni metal that is exposed to each catalyst of $\mathrm{Ni}-\mathrm{Z3}, \mathrm{Ni}-\mathrm{Z} 5$, and Ni-Z7 was $0.98 \%, 1.11 \%$, and $1.48 \%$, respectively. This value is still in accordance with theoretical calculations for the Ni metal that is embedded by $\pm 1 \%$.

Table 2. The comparison of $\mathrm{Si}, \mathrm{Al}$, and Ni elements in Ni-Z3, Ni-Z5, and Ni-Z7.

\begin{tabular}{cccc}
\hline \multirow{2}{*}{ Element } & \multicolumn{3}{c}{ Mass (\%) } \\
\cline { 2 - 4 } & Ni-Z3 & Ni-Z5 & Ni-Z7 \\
\hline $\mathrm{C}$ & 29.69 & 12.69 & 20.27 \\
$\mathrm{O}$ & 42.39 & 52.15 & 45.02 \\
$\mathrm{Si}$ & 18.58 & 23.80 & 27.38 \\
$\mathrm{Al}$ & 4.60 & 5.72 & 3.49 \\
$\mathrm{Ni}$ & 0.98 & 1.11 & 1.48 \\
$\mathrm{~S}$ & 0.55 & - & 0.80 \\
$\mathrm{~K}$ & 0.30 & 1.57 & 0.66 \\
$\mathrm{Fe}$ & 1.87 & 1.90 & - \\
$\mathrm{Zn}$ & 1.09 & - & - \\
$\mathrm{Na}$ & - & 0.48 & - \\
$\mathrm{Mg}$ & - & 0.58 & - \\
$\mathrm{Ti}$ & - & - & 0.90 \\
\hline
\end{tabular}




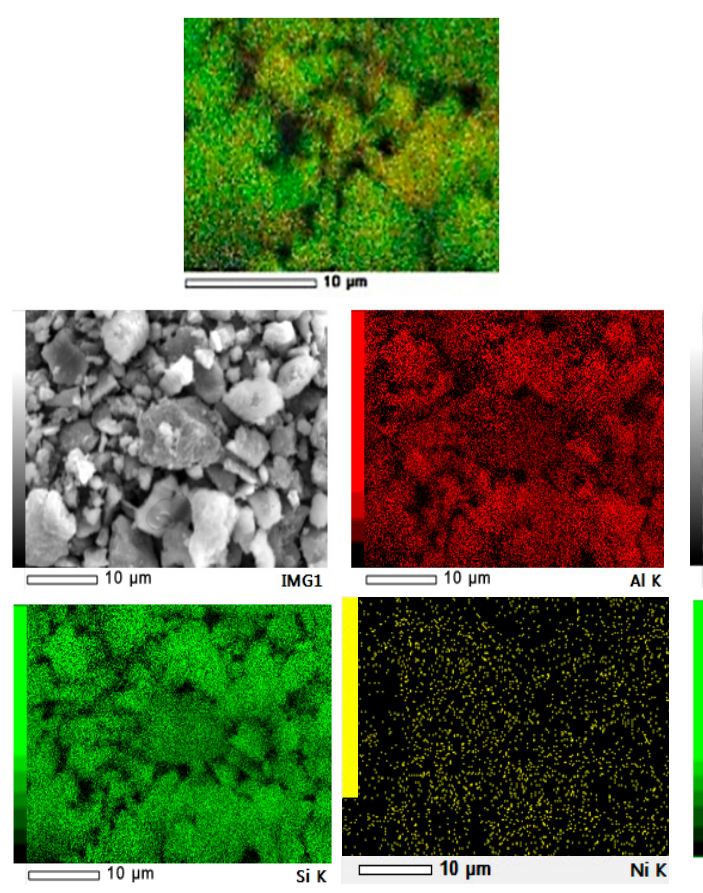

(a)
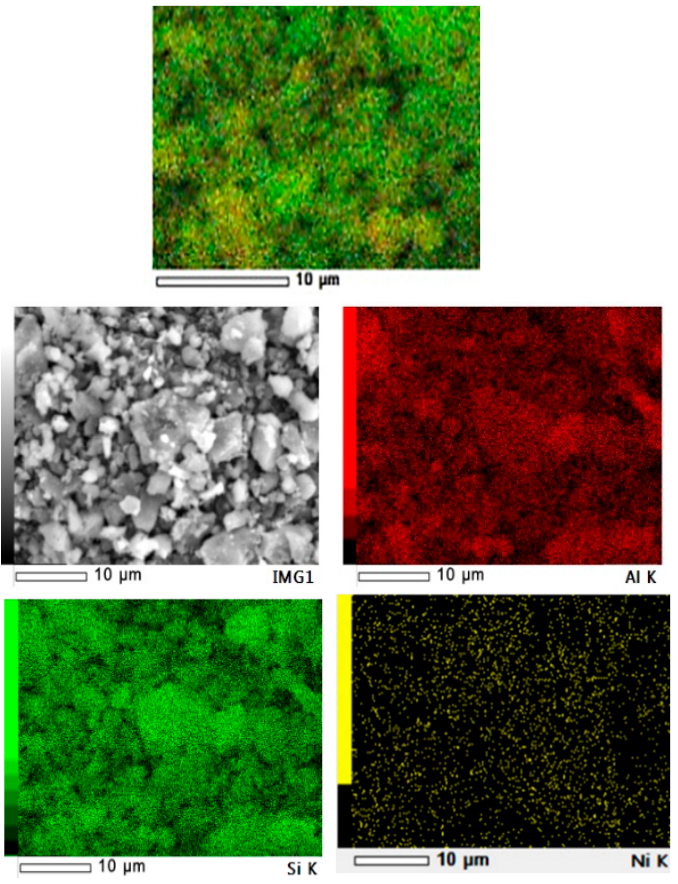

(b)
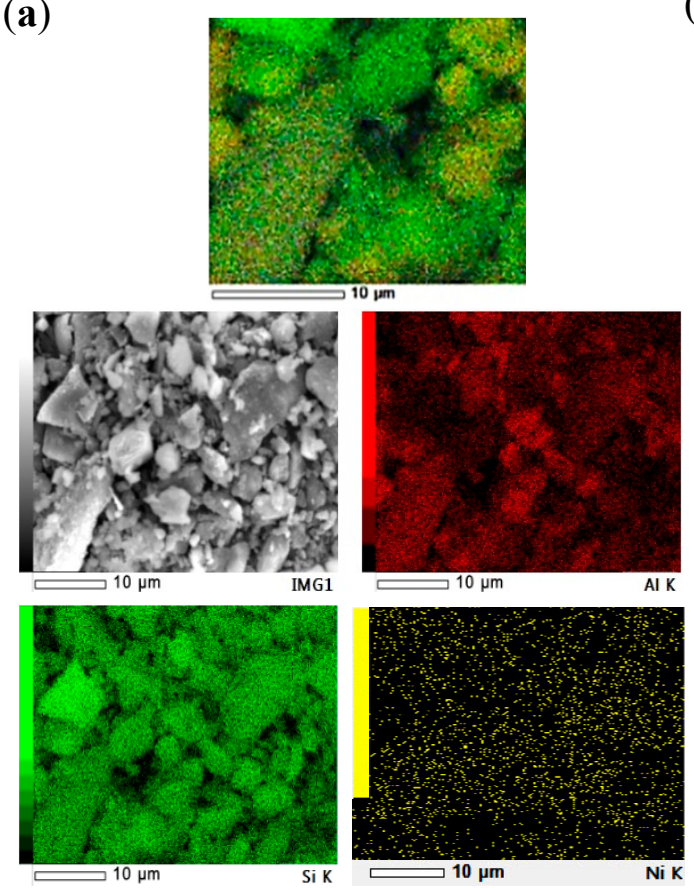

(c)

Figure 4. SEM mapping of (a) Ni-Z3, (b) Ni-Z5, and (c) Ni-Z7 catalysts.

\subsection{Specific Surface Area, Pore Volume and Size}

BET analysis was conducted with a gas sorption analyzer (GSA) to observe the characteristics of zeolite pores. Surface area, pore volume, and diameter catalyst are described in Table 3. 
Table 3. Specific surface area, pore volume, and average pore radius of Z, Z3, Z5, and Z7.

\begin{tabular}{cccc}
\hline Sample & Surface Area $\left(\mathbf{m}^{\mathbf{2}} \mathbf{g}\right)$ & Total Pore Volume $(\mathbf{c c} / \mathbf{g})$ & Average Pore Radius $(\mathbf{n m})$ \\
\hline Z & 59.60 & 0.15 & 1.722 \\
Z3 & 111.66 & 0.14 & 1.597 \\
Z5 & 132.44 & 0.20 & 1.593 \\
Z7 & 132.38 & 0.28 & 2.609 \\
$\mathrm{Ni}-Z 3$ & 72.32 & 0.15 & 1.720 \\
$\mathrm{Ni}-Z 5$ & 53.96 & 0.14 & 1.600 \\
$\mathrm{Ni}-\mathrm{Z7}$ & 107.70 & 0.21 & 1.870 \\
\hline
\end{tabular}

Based on Table 3 above, it can be observed that the activation treatment with different acid concentrations produces different specific surface area characteristics, volume pores, and average radius pores. $Z 7$ catalyst has a larger surface area, total pore volume, and pore network compared to $\mathrm{Z}, \mathrm{Z} 3$, and Z5. Acid was used to clean both crystalline and amorphous impurities that covered the zeolite pores. The activation process, with a concentration of $7 \mathrm{M} \mathrm{HCl}$, was able to optimally dissolve and remove metal oxides from $\mathrm{Fe}, \mathrm{F}, \mathrm{Ca} \mathrm{Mg}$, and $\mathrm{Ti}$, which are absorbed and cover the surface of zeolite, while also being able to optimize the amount of aluminum in the tetrahedral zeolite framework. Therefore, the $\mathrm{Z7}$ catalyst has high surface and thermal stability. The zeolite dealumination due to acid treatment only releases inactive skeleton aluminum, so that the increased amount of aluminum produces Bronsted and Lewis acid sites, which are very important for catalytic processes.

Meanwhile, the influence of metal loading on each catalyst can be seen to give the Ni-Z7 catalyst a greater surface area and the total pore volume compared to Ni-Z3 and Ni-Z5. This shows that the loading of Ni-Z7 metal was more homogeneously distributed on the surface and pore of the catalyst. Different results are shown by Ni-Z3 and Ni-Z5 catalysts, where metal loading results in decreased catalyst surface areas. This is due to the inhomogeneous distribution of metals, which results in the closure of the small zeolite pore. As a result, the surface area and pore volume of the catalyst decrease, and the pore size distribution shifts to a larger pore diameter. Uneven metal dispersion is strongly influenced by the nonuniform shape of the zeolite carrier surface. These results are consistent with the results of SEM and EDS characterization, which show that Z7 has a smoother and more uniform surface morphology.

The Z3, Z5, Ni-Z3, Ni-Z5, and Ni-Z7 catalysts are included in the micropore type, with a pore size of $<2 \mathrm{~nm}$. Meanwhile, the $Z 7$ catalyst is included in the mesoporous type, with a pore size of $>2 \mathrm{~nm}$. However, the BET analysis results provide an adsorption-desorption isotherm graphic form of each catalyst shown in Figure 5, with the presence of a hysterical loop observed at a relative pressure of 0.45-0.99. This graphic form has been reported as basen C type graphs on Brunauer-Emmett-Teller (BET) calcification $[15,21]$. The presence of hysterical loops and high graph rises at $\mathrm{P} / \mathrm{Po}$ characterize that each catalyst, Z, Z3, Z5, Z7, Ni-Z3, Ni-5, and ni-Z7, corresponds to mesoporous material. Furthermore, Figure 5 also shows that the Ni-Z7 catalyst produced a greater amount of N2 gas adsorption compared to other catalysts. This shows that this graph is strongly influenced by the pore shape and catalyst surface area.

Generally, Z7 has got bigger surface area than $\mathrm{Z}$ and Ni-Z catalysts. This is caused by contaminants that cover the pores of the $Z$ catalyst. The activation and calcination processes were able to remove contaminants and dissolve $\mathrm{Al}$ of zeolite structures: consequently, the $\mathrm{Z} 7$ surface area increases. Then, the decrease of the surface area in $\mathrm{Ni}-\mathrm{Z}$ catalyst with $\mathrm{Ni}$ metal impregnation was caused by the metal impregnated to $\mathrm{Z}$, covering the surface of the pores [25]. 


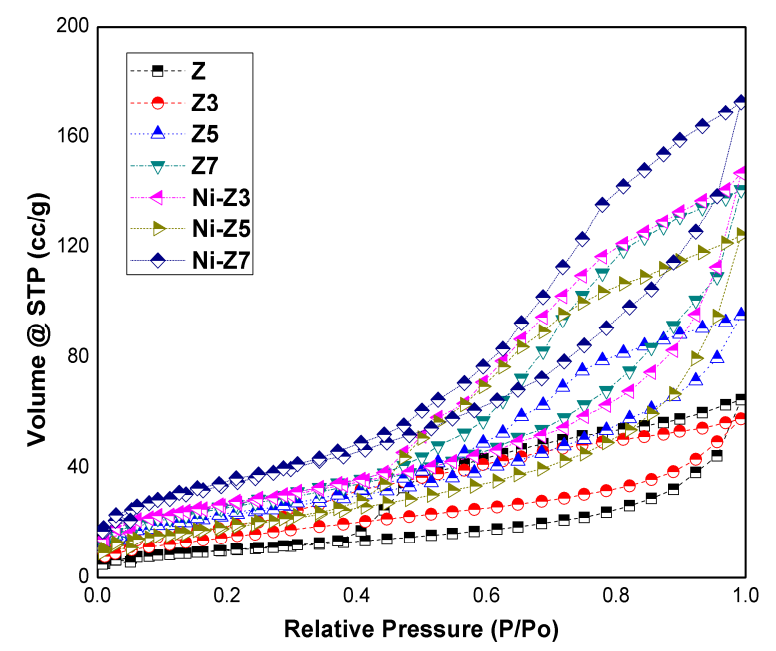

Figure 5. $\mathrm{N}_{2}$ gas adsorption-desorption isotherm comparison graph of Z, Z3, Z5, Z7, Ni-Z3, Ni-Z5, and Ni-Z7.

\subsection{Catalyst Crystallinity}

The influence of acid activation and calcination on zeolite crystallite can be observed from the change of intensity at $2 \theta$ angle by the changes of its peak intensity. The presence of the crystalline phase of zeolite is indicated by the sharp peaks in the diffractograms at $2 \theta$ areas among $18^{\circ}-28^{\circ}$ [26]. Natural zeolite of Sarulla is a modern type of zeolite [21]. The Z diffractogram is shown in Figure 6 and the intensity values at the same $2 \theta$ (degree) angle are presented in Table 4.

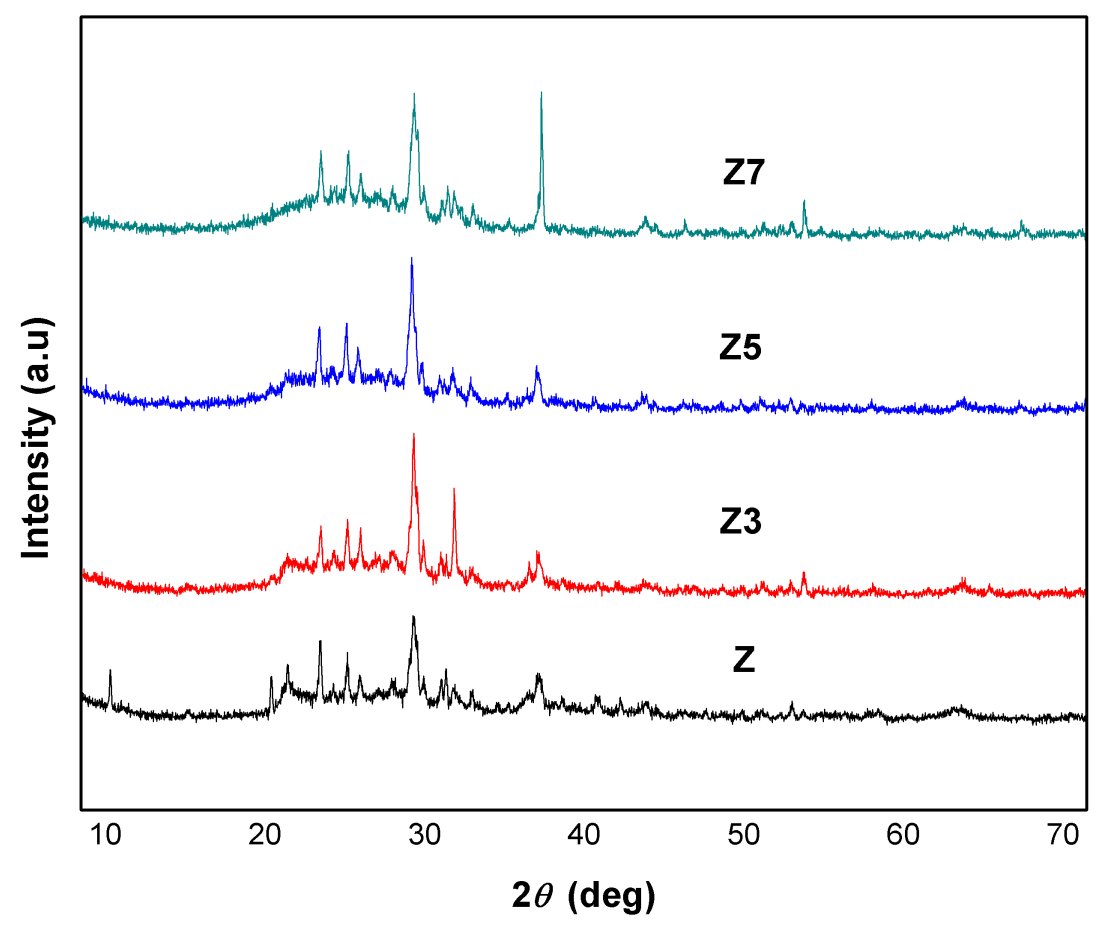

Figure 6. XRD diffractogram comparison of Z, Z3, Z5, and Z7.

Table 4 shows the comparison of intensity values at the same $2 \theta$ (degree) angle. The $Z 3$ catalyst has got the highest crystallinity compared to Z, Z5, and Z7. The rise of the intensity is due to acid activation, which can remove contaminants that cover the zeolite surface. As a result, the solid is cleaner, hence the increase of crystallinity. Sriatun and Darmawan [27] reported that the interaction of acid on the surface of zeolite would lead to the release of alumina species from zeolites. $\mathrm{H}^{+}$ions in the 
acid affect the free electrons in atom $\mathrm{O}$ to form coordination bonds. The Al-O group lacks electrons and will be more polar but less strong than before, so Al breaks from its bond. The same thing was reported by Pulungan et al. [28], who stated that the dealumination of zeolite with $\mathrm{HCl} 3 \mathrm{M}$ led to a cleaner zeolite surface and pores, as well as the increase of crystallinity. Dealumination causes the release of aluminum from the tetrahedral zeolite structure.

Table 4. $2 \theta$ (degree) peak intensity comparison of Z, Z3, Z5, and Z7.

\begin{tabular}{cccccccc}
\hline & $\mathbf{Z}$ & \multicolumn{2}{c}{$\mathrm{Z3}$} & \multicolumn{2}{c}{$\mathrm{Z5}$} & \multicolumn{2}{c}{$\mathrm{Z7}$} \\
\hline $\mathbf{2} \boldsymbol{\theta}$ & Intensity & $\mathbf{2 \theta}$ & Intensity & $\mathbf{2 \theta}$ & Intensity & $\mathbf{2 \theta}$ & Intensity \\
\hline 22.03 & 83 & 21.97 & 70 & 21.88 & 98 & 22.02 & 124 \\
23.72 & 74 & 23.66 & 77 & 23.58 & 92 & 23.71 & 121 \\
27.93 & 196 & 27.85 & 238 & 27.71 & 215 & 27.64 & 246 \\
30.43 & 42 & 30.37 & 131 & 30.26 & 42 & 30.39 & 59 \\
Crystallinity & $45.91 \%$ & Crystallinity & $50.35 \%$ & Crystallinity & $47.97 \%$ & Crystallinity & $47.95 \%$ \\
\hline
\end{tabular}

Furthermore, crystal grain size can be obtained from XRD data, calculated by the Debye-Scherrer equation [29]. Based on Table 5, it can be seen that the Z7 catalyst has the largest crystal size, between $35-41 \mathrm{~nm}$.

Table 5. Crystal grain size of Z, Z3, Z5, and Z7 catalysts.

\begin{tabular}{|c|c|c|c|c|c|c|c|}
\hline \multicolumn{2}{|c|}{$\mathrm{Z}$} & \multicolumn{2}{|c|}{ Z3 } & \multicolumn{2}{|c|}{ Z5 } & \multicolumn{2}{|c|}{ Z7 } \\
\hline $\begin{array}{c}2 \theta \\
\text { (degree) }\end{array}$ & $D(\mathrm{~nm})$ & $\begin{array}{c}2 \theta \\
\text { (degree) }\end{array}$ & $D(\mathrm{~nm})$ & $\begin{array}{c}2 \theta \\
\text { (degree) }\end{array}$ & $D(\mathrm{~nm})$ & $\begin{array}{c}2 \theta \\
\text { (degree) }\end{array}$ & $D(\mathrm{~nm})$ \\
\hline 22.03 & 27.45 & 21.97 & 27.85 & 21.88 & 25.49 & 22.02 & 41.05 \\
\hline 23.72 & 27.46 & 23.66 & 30.06 & 23.58 & 25.47 & 23.71 & 40.24 \\
\hline 27.93 & 16.71 & 27.85 & 18.97 & 27.71 & 18.10 & 27.64 & 41.51 \\
\hline 30.43 & 19.60 & 30.37 & 31.10 & 30.26 & 20.99 & 30.39 & 35.47 \\
\hline
\end{tabular}

$\mathrm{Ni}$ metal impregnated in catalysts Ni-Z3, Ni-Z5, and Ni-Z7 was detected at $2 \theta=62.52^{\circ}, 62.32^{\circ}$, and $62.80^{\circ}$, respectively. The data align with a report from Zhang et al. [30], where Ni metal was detected at $2 \theta=62.90^{\circ}$.

The XRD diffractogram and the calculation of the crystallinity degree of the Ni- $\mathrm{Z}$ catalyst are described in Figure 7 and Table 6 respectively. Ni-Z3 has got the highest crystallinity at $46.76 \%$, while its lowest crystallinity is $34.15 \%$. The hydrochloric acid $3 \mathrm{M}$ activation step in Ni-Z3 has removed the contaminants on the zeolite surface. A cleaner zeolite surface gives higher intensity as X-ray diffraction is not blocked by any impurities [31].

Table 6. $2 \theta$ (degree) peak intensity comparison of Ni-Z3, Ni-Z5, and Ni-Z7 diffractograms.

\begin{tabular}{cccccc}
\hline \multicolumn{2}{c}{ Ni-Z3 } & \multicolumn{2}{c}{ Ni-Z5 } & \multicolumn{2}{c}{ Ni-Z7 } \\
\hline $\mathbf{2 \theta}$ (degree) & Intensity & $\mathbf{2 \theta}$ (degree) & Intensity & $\mathbf{2 \theta}$ (degree) & Intensity \\
\hline 19.90 & 46 & 19.56 & 19 & 19.77 & 20 \\
21.12 & 59 & 21.42 & 23 & 21.88 & 60 \\
23.62 & 59 & 23.73 & 74 & 23.52 & 54 \\
27.78 & 248 & 27.89 & 228 & 27.79 & 163 \\
30.31 & 46 & 30.46 & 61 & 30.24 & 32 \\
Crystallinity & $46.76 \%$ & Crystallinity & $42.49 \%$ & Crystallinity & $34.15 \%$ \\
\hline
\end{tabular}




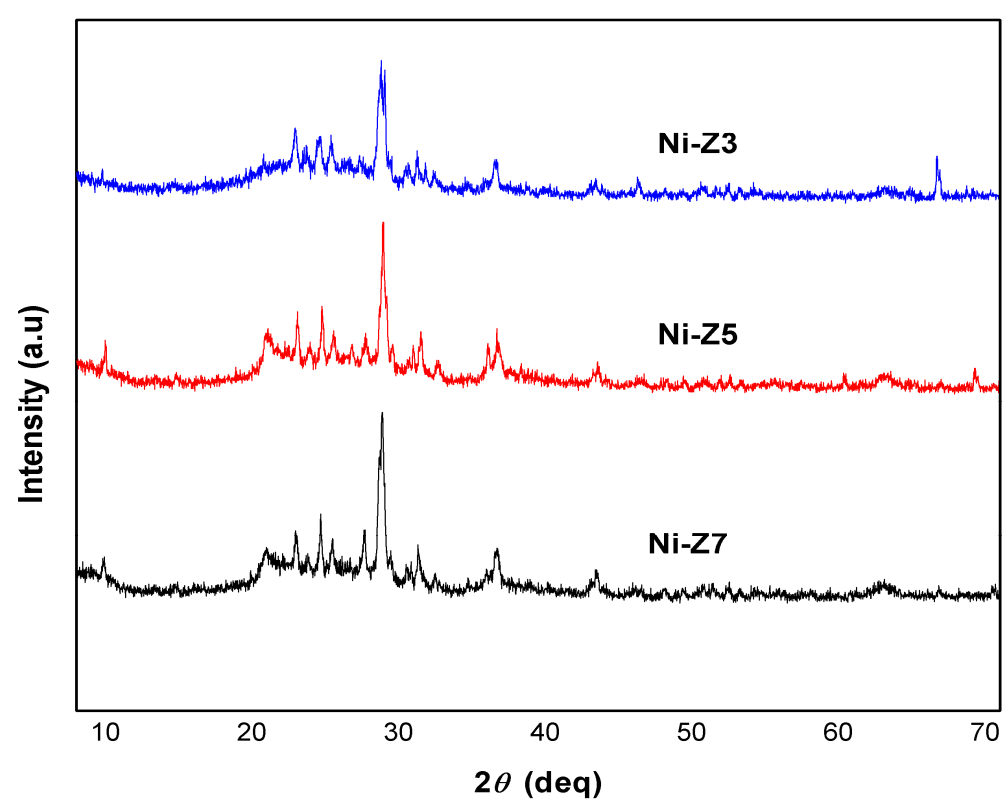

Figure 7. XRD diffractogram patterns of Ni-Z3, Ni-Z5, and Ni-Z7.

Catalyst activation by using hydrochloric acid of 5 and $7 \mathrm{~mol} / \mathrm{L}$ leads to lower crystallinity. It is suspected that the acid has also dissolved $\mathrm{Al}$, where parts of $\mathrm{Al}$ and the impurities are removed from the zeolite structure. This case is supported by the EDS data in Table 2. The crystal size of each catalyst is presented in Table 7 .

Table 7. Crystal grain size of Ni-Z3, Ni-Z5, and Ni-Z7 catalysts.

\begin{tabular}{cccccc}
\hline \multicolumn{2}{c}{ Ni-Z3 } & \multicolumn{2}{c}{ Ni-Z5 } & \multicolumn{2}{c}{ Ni-Z7 } \\
\hline $\mathbf{2 \theta}$ (degree) & $\boldsymbol{D}(\mathbf{n m})$ & $\mathbf{2 \theta}$ (degree) & $\boldsymbol{D}(\mathbf{n m})$ & $\mathbf{2 \theta}$ (degree) & $\boldsymbol{D}(\mathbf{n m})$ \\
\hline 21.12 & 22.73 & 21.42 & 40.42 & 21.88 & 19.28 \\
23.62 & 25.39 & 23.73 & 35.55 & 23.52 & 19.50 \\
27.78 & 16.90 & 27.89 & 26.11 & 27.19 & 13.34 \\
30.31 & 22.61 & 30.46 & 32.93 & 30.24 & 21.26 \\
\hline
\end{tabular}

Based on the calculation of zeolite crystal grain sizes in Table 7, the Ni-Z7 catalyst has the smallest crystal size at $13-21 \mathrm{~nm}$, while the biggest crystal size was possessed by Ni-Z5 at $40 \mathrm{~nm}$. This result is supported by the surface morphology from the SEM analysis in Figure 2.

\subsection{Hydrodeoxygenation (HDO) Process}

The HDO reaction can be generally written as follows:

$$
-\left(\mathrm{CH}_{2} \mathrm{O}\right)-+\mathrm{H}_{2} \rightarrow-\left(\mathrm{CH}_{2}\right)-+\mathrm{H}_{2} \mathrm{O}
$$

The oxygen content of samples is reduced by reaction with hydrogen in the presence of a suitable catalyst, producing water as one of the major byproducts.

Commercial liquid smoke and the product of HDO characteristics are concluded in Table 8. The density of liquid smoke did not change after HDO, whereas water content dropped by $5-21 \%$. Liquid smoke's $\mathrm{pH}$ generally decreased after HDO due to the formation of carboxylic acid, which increased from $0.84 \%$ to $7.45 \%$, as presented in Figure 8 . 
Table 8. Characteristics of commercial liquid smoke and HDO product.

\begin{tabular}{cccc}
\hline Catalysts & $\mathbf{p H}$ & Density $(\mathrm{g} / \mathrm{mL})$ & Water Content $(\%)$ \\
\hline Commercial Liquid Smoke & 4.0 & 1.049 & 89.97 \\
Z3 & 4.0 & 1.048 & 68.71 \\
Z5 & 3.9 & 1.047 & 84.46 \\
Z7 & 3.8 & 1.047 & 82.47 \\
Ni-Z3 & 3.4 & 1.050 & 78.86 \\
Ni-Z5 & 3.6 & 1.048 & 68.06 \\
Ni-Z7 & 3.4 & 1.046 & 77.31 \\
\hline
\end{tabular}

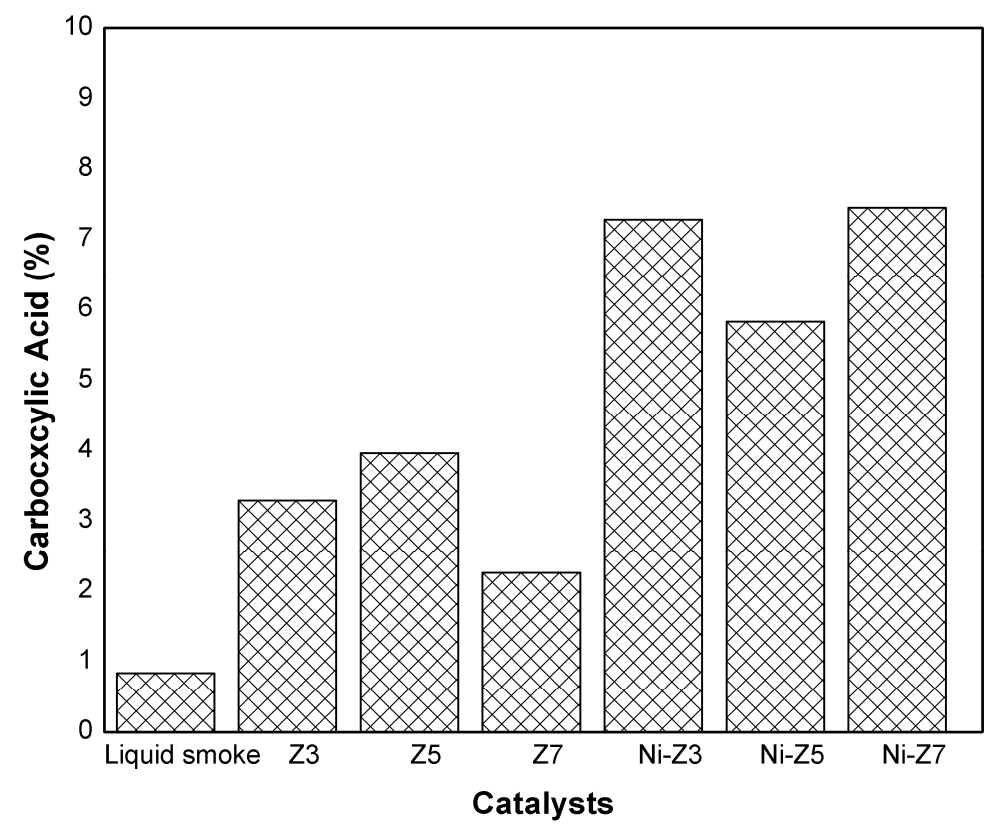

Figure 8. Carboxylic acid percentage in liquid smoke HDO product.

\subsection{Composition of Liquid Smoke of the HDO Product}

GC-MS analysis of liquid smoke of the HDO product using Z3, Z5, Z7, Ni-Z3, Ni-Z5, and Ni-Z7 catalysts, as well as their compound-shifting data of liquid smoke, are listed in Table 9.

Those compounds can be categorized into groups of categories, such as phenol, alkoxy, carboxylic acid, cycloalkane, and alcohol groups. In this research, the observation is on alteration of the phenol group and its derivatives, such as phenol and methyl phenol and alkoxy groups, into oxygenate compounds such as guaiacol and methyl guaiacol. Based on Table 9 lists, the main components of untreated liquid smoke are phenol groups. Generally, phenol and its derivative content increase after HDO, either with acid-activated catalysts or Ni-loaded catalysts.

Figure 9 displays the comparison of phenol and alkoxy contents related to respective catalysts. Phenol and its derivatives increased to $62.93 \%$ and $60.93 \%$ using Z3 and Z5 and decreased to $36.21 \%$ using Z7. Compared to initial content, $55.46 \%$, Z3 and Z5 increased phenol and its derivatives $14 \%$ and $9 \%$, while Z7 decreased it significantly by $35 \%$. By using Ni-loaded catalysts, phenol content increased $57.88 \%, 60.06 \%$, and $56.52 \%$ for Ni-Z3, Ni-Z5, and Ni-Z7.

Another shifted compound that was being particularly observed is the alkoxy group. The Alkoxy group, the initial content of which was $28.18 \%$, decreased to $11.93 \%, 12.27 \%$, and $6.91 \%$ after HDO using Z3, Z5, and Z7, respectively. The same impact was also shown by Ni-Z3, Ni-Z5, and Ni-Z7 as well, decreasing the alkoxy content to $11.61 \%, 11.49 \%$, and $11.66 \%$, respectively. 
Table 9. Main components in commercial and HDO liquid smoke.

\begin{tabular}{cccccccc}
\hline Compound & \multicolumn{7}{c}{ \% Area } \\
\cline { 2 - 8 } & Initial & Z3 & Z5 & Z7 & Ni-Z3 & Ni-Z5 & Ni-Z7 \\
\hline Phenol & 31.61 & 32.48 & 26.27 & 16.69 & 28.41 & 30.00 & 26.70 \\
Phenol,2-methyl & 8.35 & - & 1.90 & 1.60 & 1.27 & 1.87 & 1.21 \\
Phenol,4-methyl & 8.49 & - & - & - & - & - & - \\
Guaiacol & 12.37 & 1.57 & 1.41 & 0.82 & 1.56 & 1.69 & 1.61 \\
Phenol,2,6-dimethyl & 0.72 & - & - & - & - & - & - \\
Phenol, 2-ethyl & 0.77 & - & - & - & - & - & - \\
Phenol,3,5-dimethyl & 1.92 & - & - & - & - & - & - \\
Phenol,3-ethyl & 1.45 & - & - & - & - & - & - \\
4-methylguaiacol & 7.57 & - & - & - & - & - & - \\
Phenol,2-ethyl-5-methyl & 0.69 & - & - & - & - & - & - \\
Phenol,3,4-dimethoxy & 0.15 & - & - & - & - & - & - \\
1,2-benzenediol,3-methoxy & 1.45 & 1.98 & 2.28 & 1.22 & 1.67 & 1.73 & 1.79 \\
Phenol,4-ethyl-2-methoxy & 2.51 & 0.83 & 0.80 & 0.43 & 0.71 & 0.66 & 0.63 \\
1,2-benzenediol,4-methyl & 0.87 & 4.18 & 4.86 & 2.66 & 3.39 & 3.81 & 3.58 \\
Phenol,2,6-dimethoxy & 4.13 & 7.55 & 7.78 & 4.44 & 7.67 & 7.41 & 7.63 \\
1.3-benzenediol,4-ethyl & 0.59 & 1.70 & 2.00 & 1.10 & 1.43 & 1.55 & - \\
Phenol,3-methyl & - & 2.51 & 2.24 & 1.41 & 2.75 & 2.53 & 2.56 \\
Catechol & - & 15.67 & 16.49 & 9.13 & 14.60 & 14.69 & 16.34 \\
1,2-benzenediol,3-methyl & - & 2.19 & 2.45 & 1.39 & 2.16 & 2.13 & 2.25 \\
Hydroquinone & - & 2.74 & 3.14 & 1.67 & 2.93 & 2.66 & 2.91 \\
1,4-benzenediol,2-methyl & - & 0.92 & 1.04 & 0.56 & 0.94 & 0.82 & 0.97 \\
\hline
\end{tabular}

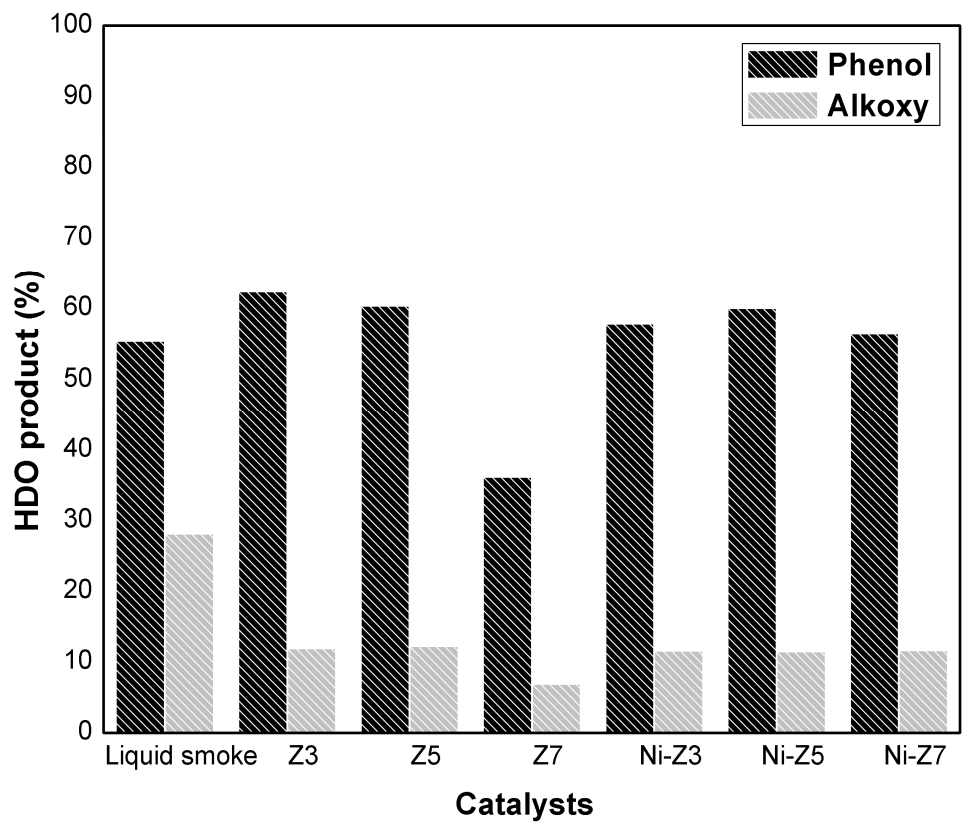

Figure 9. The effect of catalyst variations on HDO products.

Guaiacol (2-methoxyphenol), one of the main components shown in Table 9 decreased significantly after HDO. It might be caused by guaiacol conversion into methane and catechol. Guaiacol also can be directly converted to phenol through the hydrogenolysis of the methoxy group [32-34]. Putri and Nugrahaningtyas [35] reported that catechol and phenol were the primary products, with high composition from guaiacol conversion. Then, catechol can be converted to phenol through the hydrogenolysis of the hydroxyl group. Guaiacol, with content of $12.37 \%$, decreased after HDO, while catechol as a new detected compound has high content either with $\mathrm{Z}$ or Ni-Z catalysts. 
The compound of 2-methoxy-4-methylphenol (4-methylguaiacol) was also shifted. Its initial content of $7.57 \%$ was no longer detected after HDO. The conversion of the 4-methylguaiacol compound, which went through demethylation (DME) to become 1,2-benzenediol,4-methyl (4-methylcathecol) and deoxygenation (DDO) to become 3-methylanisole, was reported by Bouxin et al. [36]. 4-methylcatecholthrough DDO can be converted to phenol-3-methyl (m-cresol), and 3-methylanisolethrough DME can be converted to m-cresol. As presented in Table 9, 4-methylcathecol is seen to be increasing from $0.87 \%$ to $2.66-4.86 \%$, and m-cresol, which initially did not exist, was detected after HDO with a content of $2.75 \%$.

\subsection{Catalyst Activity and Selectivity in Hydrodeoxygenation Reaction}

The characteristics of zeolite as a catalyst can affect the selectivity of the conversion of oxygenate to phenol and its derivatives. The surface morphology of the catalysts observed through SEM and EDX shows a homogeneous crystalline grain size and reduced impurity levels after the dealumination and impregnation of $\mathrm{Ni}$. Such a catalyst surface allows the HDO reaction to run more optimally, without impurities that will interfere with the reaction.

The highest surface area, total pore volume, and average pore are indicated by the $Z 7$ catalyst, followed by Z5 and Ni-Z7 catalysts. A wider surface on the catalyst allows a greater area for the HDO reaction. A large total pore volume allows more frequent adsorption-desorption processes on the catalyst. Z5 catalyst with the highest surface area reached $132.44 \mathrm{~m}^{2} / \mathrm{g}$ and total pore volume reached $0.207 \mathrm{cc} / \mathrm{g}$, resulting in a total phenol content high enough to reach $60.39 \%$.

Crystal size zeolite catalysts for acid activation and Ni-zeolite in this study are all included in the mesoporous size in the range of 13-41 nm. Mesoporous material is reported to have fast diffusion and is accessible for bulky molecules [37]. For HDO reactions of liquid smoke in this study, catalysts Z3, Z5, Ni-Z3, and Ni-Z5, which have larger crystalline sizes, have a higher total conversion of alkoxy compounds to phenols compared to Ni-Z7 catalysts, which have the smallest crystal sizes. The increased mesoporosity improved the accessebility of acid sites and could also give great performance in many other acid-catalyzed reactions involving bulky molecules [38].

In a bifunctional catalyst, the metal site acts as hydrogenation and the Bronsted acid site on the zeolite has a role in the dehydration reaction. The center of the metal accelerates the rate of dehydration for phenols at the Bronsted acid site in zeolite, where on the other hand, the Bronsted acid site increases the HDO rate that is taking place in the bifunctional reaction [18]. The Bronsted acid site in zeolite binds with hydrogen and it easily releases the hydrogen to react with the hydrodeoxygenated compounds [39]. The catalytic performance of Ni-Z-reducing oxygenate compounds is better than the $\mathrm{Z}$ catalyst.

In the HDO reaction, the HDO process with the Ni-metal-impregnated zeolite catalyst in NZ is better at reducing alkoxy compounds in liquid smoke than nonimpregnated zeolite catalysts. In a bifunctional catalyst, the metal site acts as hydrogenation and the Bronsted acid site on zeolite has a role in the dehydration reaction. The center of the metal accelerates the rate of dehydration for phenols at the Bronsted acid site in zeolite, where on the other hand, Bronsted acid site increases the HDO rate that is taking place in the bifunctional reaction [18]. In the guaiacol conversion to catechol reaction using the bifunctional $\mathrm{NZ}$ catalyst, demethylation, or the direct release of $\mathrm{CH}_{4}$ (methyl), occurs. $\mathrm{H}_{2}$ gas binds with $\mathrm{CH}_{3}$ to form $\mathrm{CH}_{4}$, whereas other compounds bind with $\mathrm{Ni}$ metal. Then, $\mathrm{H}^{+}$from the Bronsted acid in zeolite is bonded by atom $\mathrm{O}$ from guaiacol that had lost $\mathrm{CH}_{3}$ and catechol is formed [35].

The Ni-Z5 catalyst is considered to support HDO catalytic activity better than other catalysts, as seen from the decrease in alkoxy compounds that reached $11.49 \%$. Judging from the properties of the catalyst, Ni-Z5 has the least amount of carbon, where the amount of deposited carbon can cover the surface of the catalyst so that it interferes with catalytic activity. In addition, this catalyst has a large crystal size.

Overall, liquid smoke as the product of HDO with the Z7 catalyst experiences a decrease in phenol, alkoxy and other functional groups. This is suspected to be the deactivation of the catalyst due to the fouling occurring on the surface. Zhao et al. [40] reported that catechol—the same compound 
found in liquid smoke from HDO in the research—has more tendency to cause fouling than phenol. The fouling during HDO usually occurs in a more acidic catalyst [41,42]. The formation of fouling is related to the acidity of catalyst, including the Lewis and Bronsted acid sites, where it rises with the increase in acidity [43]. Acidity is responsible for the activation of reactants, as well as having a role in catalyst deactivation. Therefore, it is required to observe the right amount and strength of acidity so the formation of fouling is limited during HDO [44].

\section{Conclusions}

The HDO process of liquid smoke causes the rise in contents of phenol and its derivatives, as well as the decrease of alkoxy group compounds as the result of guaiacol conversion to phenol and catechol, along with the conversion of 4-methylguaiacol to 4-methylcathecol and m-cresol. HDO with the Z3 catalyst obtained the highest contents of phenol and its derivatives at $62.39 \%$, with an $11.93 \%$ reduction of alkoxy compounds, whereas, the Ni-metal-impregnated catalyst also experienced an increase in phenol content, in which the highest content is observed from the Ni-Z5 catalyst at $60.06 \%$, with an $11.49 \%$ reduction of alkoxy content. Finally, further research with the utilization of various metals also needs to be explored in order to achieve optimum results.

Author Contributions: Conceptualization, S.G., A.H., and A.A.; data curation, J.L.S. and A.N.P.; formal analysis, S.G.; investigation, J.L.S., A.N.P., T.N., and R.R.; methodology, S.G., A.H., and J.L.S.; software, J.L.S. and A.N.P.; supervision, S.G., A.H., and A.A.; visualization, J.L.S., A.N.P., and Y.A.H.; writing-original draft, J.L.S.; writing-review and editing, S.G. and Y.A.H. All authors have read and agreed to the published version of the manuscript.

Funding: This research was funded by Universitas Sumatera Utara via the Domestic Research Collaboration Scheme of TALENTA USU 2019 with grant number of 4176/UN5.1.R/PPM/2019.

Acknowledgments: Authors would like to acknowledge the Rector of Universitas Sumatera Utara for the financial support provided via the Domestic Research Collaboration Scheme of TALENTA USU 2019 (No. 4176/UN5.1.R/PPM/2019).

Conflicts of Interest: The authors declare no conflict of interest.

\section{References}

1. Hasanah, U.; Setiaji, B.; Triyono, T.; Anwar, C. The Chemical Composition and Physical Properties of the Light and Heavy Tar Resulted from Coconut Shell Pyrolysis. J. Pure Appl. Chem. Res. 2012, 1, 26-32. [CrossRef]

2. Hadanu, R.; Apituley, D.A.N. Volatile Compounds Detected in Coconut Shell Liquid Smoke through Pyrolysis at a Fractioning Temperature of 350-420 ${ }^{\circ}$ C. Makara J. Sci. 2016, 20, 95-100. [CrossRef]

3. Nugrahaningtyas, K.D.; Hidayat, Y.; Prayekti, P.S. Aktivitas Dan Selektivitas Katalis Mo-Co/USY Pada Reaksi Hidrodeoksigenasi Anisol. J. Penelit. Saintek 2015, 20, 19-28. [CrossRef]

4. Dickerson, T.; Soria, J. Catalytic Fast Pyrolysis: A Review. Energies 2013, 6, 514-538. [CrossRef]

5. Si, Z.; Zhang, X.; Wang, C.; Ma, L.; Dong, R. An Overview on Catalytic Hydrodeoxygenation of Pyrolysis Oil and Its Model Compounds. Catalysts 2017, 7, 169. [CrossRef]

6. Cheng, S.; Wei, L.; Zhao, X.; Julson, J. Application, Deactivation, and Regeneration of Heterogeneous Catalysts in Bio-Oil Upgrading. Catalysts 2016, 6, 195. [CrossRef]

7. Nie, L.; De Souza, P.M.; Noronha, F.B.; An, W.; Sooknoi, T.; Resasco, D.E. Selective Conversion of M-Cresol to Toluene over Bimetallic Ni-Fe Catalysts. J. Mol. Catal. A Chem. 2014, 388-389, 47-55. [CrossRef]

8. Ly, H.V.; Choi, J.H.; Woo, H.C.; Kim, S.S.; Kim, J. Upgrading Bio-Oil by Catalytic Fast Pyrolysis of Acid-Washed Saccharina Japonica Alga in a Fluidized-Bed Reactor. Renew. Energy 2019, 133, 11-22. [CrossRef]

9. Schmitt, C.C.; Reolon, M.B.G.; Zimmermann, M.; Raffelt, K.; Grunwaldt, J.D.; Dahmen, N. Synthesis and Regeneration of Nickel-Based Catalysts for Hydrodeoxygenation of Beech Wood Fast Pyrolysis Bio-Oil. Catalysts 2018, 8, 449. [CrossRef]

10. Lee, H.; Kim, H.; Yu, M.J.; Ko, C.H.; Jeon, J.K.; Jae, J.; Park, S.H.; Jung, S.C.; Park, Y.K. Catalytic Hydrodeoxygenation of Bio-Oil Model Compounds over Pt/HY Catalyst. Sci. Rep. 2016, 6, 1-8. [CrossRef]

11. Shamanaev, I.V.; Deliy, I.V.; Gerasimov, E.Y.; Pakharukova, V.P.; Bukhtiyarova, G.A. Enhancement of HDO Activity of MoP/SiO2 Catalyst in Physical Mixture with Alumina or Zeolites. Catalysts 2019, 10, 45. [CrossRef] 
12. Ameen, M.; Azizan, M.T.; Yusup, S.; Ramli, A.; Yasir, M.; Kaur, H.; Wai, C.K. H-Y Zeolite as Hydrodeoxygenation Catalyst for Diesel Range Hydrocarbon Production from Rubber Seed Oil. In Materials Today: Proceedings; Elsevier Ltd.: Langkawi, Malaysia, 2019; Volume 16, pp. 1742-1749. [CrossRef]

13. Feng, J.; Hse, C.-Y.; Yang, Z.; Wang, K.; Jiang, J.; Xu, J. Liquid Phase in Situ Hydrodeoxygenation of Biomass-Derived Phenolic Compounds to Hydrocarbons over Bifunctional Catalysts. Appl. Catal. A Gen. 2017, 542, 163-173. [CrossRef]

14. Ayodele, O.B.; Farouk, H.U.; Mohammed, J.; Uemura, Y.; Daud, W.M.A.W. Hydrodeoxygenation of Oleic Acid into N- and Iso-Paraffin Biofuel Using Zeolite Supported Fluoro-Oxalate Modified Molybdenum Catalyst: Kinetics Study. J. Taiwan Inst. Chem. Eng. 2015, 50, 142-152. [CrossRef]

15. Sihombing, J.L.; Gea, S.; Wirjosentono, B.; Agusnar, H.; Pulungan, A.N.; Herlinawati, H.; Yusuf, M.; Hutapea, Y.A. Characteristic and Catalytic Performance of Co and Co-Mo Metal Impregnated in Sarulla Natural Zeolite Catalyst for Hydrocracking of MEFA Rubber Seed Oil into Biogasoline Fraction. Catalysts 2020, 10, 121. [CrossRef]

16. Sriningsih, W.; Saerodji, M.G.; Trisunaryanti, W.; Triyono; Armunanto, R.; Falah, I.I. Fuel Production from LDPE Plastic Waste over Natural Zeolite Supported Ni, Ni-Mo, Co and Co-Mo Metals. Procedia Environ. Sci. 2014, 20, 215-224. [CrossRef]

17. Rahayu, F.L.; Nuryanto, R.; Suyati, L. Pengaruh Diameter Kanal Pelet Katalis Zeolit Aktif Dan Ni-Zeolit Terhadap Pirolisis Limbah Batang Pohon Sagu (Metroxylonsp.). J. Kim. Sains Dan Apl. 2013, 16, 33. [CrossRef]

18. Shi, Y.; Xing, E.; Wu, K.; Wang, J.; Yang, M.; Wu, Y. Recent Progress on Upgrading of Bio-Oil to Hydrocarbons over Metal/Zeolite Bifunctional Catalysts. Catal. Sci. Technol. 2017, 7, 2385-2415. [CrossRef]

19. Yu, Z.; Wang, Y.; Sun, Z.; Li, X.; Wang, A.; Camaioni, D.M.; Lercher, J.A. Ni3P as a High-Performance Catalytic Phase for the Hydrodeoxygenation of Phenolic Compounds. Green Chem. 2018, 20, 609-619. [CrossRef]

20. Prihatini, D.; Ulfa, S.M.; Iftitah, E.D. Uji Aktivitas Katalis Ni/ZrO2-SiO2 Untuk Reaksi Hidrodeoksigenasi Campuran Senyawa Furfurilidena Aseton (FAc) Dan Difurfurilidena Aseton (F2Ac). Natural 2016, 3, $253-259$.

21. Sihombing, J.L.; Gea, S.; Pulungan, A.N.; Agusnar, H.; Wirjosentono, B.; Hutapea, Y.A. The Characterization of Sarulla Natural Zeolite Crystal and Its Morphological Structure. In AIP Conference Proceedings; American Institute of Physics Inc.: Surabaya, Indonesia, 2018; Volume 2049, p. 020062. [CrossRef]

22. Sari, R.M.; Gea, S.; Wirjosentono, B.; Hendrana, S.; Hutapea, Y.A. Improving Quality and Yield Productionof Coconut Shell Charcoal Through a Modified Reactor with Tar Scrubberto Reduce Smoke Pollution. Polish J. Environ. Stud. 2020, 29, 1815-1824. [CrossRef]

23. Prasetyo, A.; Nafsiati, R.; Kholifah, S.N.; Botianovi, A. Analisis Permukaan Zeolit Alam Malang Yang Mengalami Modifikasi Pori Dengan Uji SEM-EDS. SAINTIS 2012, 1, 39-46. [CrossRef]

24. Sentosa, L.; Subagio, B.S.; Rahman, H.; Yamin, R.A. Aktivasi Zeolit Alam Asal Bayah Dengan Asam Dan Basa Sebagai Aditif Campuran Beraspal Hangat (Warm Mixed Asphalt (WMA)). J. Tek. Sipil 2018, 25, 203. [CrossRef]

25. Pertiwi, R.; Tursiloadi, S.; Adilina, I.B.; Sembiring, K.C.; Oaki, Y. Nickel Supported Natural Zeolite as a Bifunctional Catalysts for Conversion of Citronella Oil Crude to Menthols. J. Kim. Terap. Indones. 2017, 18, 132-138. [CrossRef]

26. Suharto, T.E.; Gustin, I.; Sudaryono, A. Pembuatan Dan Karakterisasi Katalis Bifungsional Dari Zeolit Alam. J. Gradien 2007, 3, 267-272.

27. Sriatun, S.; Darmawan, A. Dealuminasi zeolit alam cipatujah melalui penambahan asam dan oksidator. J. Kim. Sains Dan Apl. 2005, 8, 55-60. [CrossRef]

28. Pulungan, A.N.; Sihombing, J.L.; Nasution, H.I.; Syafriani, D.; Wibowo, A.A. Study of Rubber Seed Oil into Biodiesel Fraction with Hetergen Acid Catalyst. In International Seminar on Trends in Science and Science Education; Faculty of Mathematics and Natural Sciences, Universitas Negeri Medan: Medan, Indonesia, 2015.

29. Cullity, D.B. Elements of X-Ray Diffraction; Addison-Wesley: London, UK, 1959.

30. Zhang, X.; Zhang, Q.; Chen, L.; Xu, Y.; Wang, T.; Ma, L. Effect of Calcination Temperature of Ni/SiO2-ZrO2 Catalyst on Its Hydrodeoxygenation of Guaiacol. Cuihua Xuebao/Chinese J. Catal. 2014, 35, 302-309. [CrossRef]

31. Pardoyo, P.; Listiana, L.; Darmawan, A. Pengaruh Perlakuan HCl Pada Kristalinitas Dan Kemampuan Adsorpsi Zeolit Alam Terhadap Ion Ca2+. J. Sains dan Mat. 2009, 17, 100-104.

32. Sun, J.; Karim, A.M.; Zhang, H.; Kovarik, L.; Li, X.S.; Hensley, A.J.; McEwen, J.S.; Wang, Y. Carbon-Supported Bimetallic Pd-Fe Catalysts for Vapor-Phase Hydrodeoxygenation of Guaiacol. J. Catal. 2013, 306, 47-57. [CrossRef] 
33. Grilc, M.; Likozar, B.; Levec, J. Hydrodeoxygenation and Hydrocracking of Solvolysed Lignocellulosic Biomass by Oxide, Reduced and Sulphide Form of NiMo, Ni, Mo and Pd Catalysts. Appl. Catal. B Environ. 2014, 150-151, 275-287. [CrossRef]

34. Espro, C.; Gumina, B.; Paone, E.; Mauriello, F. Upgrading Lignocellulosic Biomasses: Hydrogenolysis of Platform Derived Molecules Promoted by Heterogeneous Pd-Fe Catalysts. Catalysts 2017, 7, 78. [CrossRef]

35. Putri, I.F.; Nugrahaningtyas, K.D. Kajian Aktivitas Katalitik CoMo/Al2O3 Pada Reaksi Hidrodeoksigenasi Anisol Dan Guaiacol. J. Kim. dan Pendidik. Kim. 2016, 1, 164-173.

36. Bouxin, F.P.; Zhang, X.; Kings, I.N.; Lee, A.F.; Simmons, M.J.H.; Wilson, K.; Jackson, S.D. Deactivation Study of the Hydrodeoxygenation of P-Methylguaiacol over Silica Supported Rhodium and Platinum Catalysts. Appl. Catal. A Gen. 2017, 539, 29-37. [CrossRef]

37. Zhu, J.; Meng, X.; Xiao, F. Mesoporous Zeolites as Efficient Catalysts for Oil Refining and Natural Gas Conversion. Front. Chem. Sci. Eng. 2013, 7, 233-248. [CrossRef]

38. Hao, W.; Zhang, W.; Guo, Z.; Ma, J.; Li, R. Mesoporous Beta Zeolite Catalysts for Benzylation of Naphthalene: Effect of Pore Structure and Acidity. Catalysts 2018, 8, 504. [CrossRef]

39. Wang, W.; Yang, Y.; Luo, H.; Hu, T.; Liu, W. Preparation and Hydrodeoxygenation Properties of Co-Mo-O-B Amorphous Catalyst. React. Kinet. Mech. Catal. 2011, 102, 207-217. [CrossRef]

40. Zhao, H.Y.; Li, D.; Bui, P.; Oyama, S.T. Hydrodeoxygenation of Guaiacol as Model Compound for Pyrolysis Oil on Transition Metal Phosphide Hydroprocessing Catalysts. Appl. Catal. A Gen. 2011, 391, 305-310. [CrossRef]

41. Ghampson, I.T.; Sepúlveda, C.; Garcia, R.; Radovic, L.R.; Fierro, J.L.G.; Desisto, W.J.; Escalona, N. Hydrodeoxygenation of Guaiacol over Carbon-Supported Molybdenum Nitride Catalysts: Effects of Nitriding Methods and Support Properties. Appl. Catal. A Gen. 2012, 439-440, 111-124. [CrossRef]

42. Shetty, M.; Murugappan, K.; Green, W.H.; Román-Leshkov, Y. Structural Properties and Reactivity Trends of Molybdenum Oxide Catalysts Supported on Zirconia for the Hydrodeoxygenation of Anisole. ACS Sustain. Chem. Eng. 2017, 5, 5293-5301. [CrossRef]

43. Mortensen, P.M.; Grunwaldt, J.D.; Jensen, P.A.; Knudsen, K.G.; Jensen, A.D. A Review of Catalytic Upgrading of Bio-Oil to Engine Fuels. Appl. Catal. A General. 2011, 1-19. [CrossRef]

44. He, Z.; Wang, X. Hydrodeoxygenation of Model Compounds and Catalytic Systems for Pyrolysis Bio-Oils Upgrading. Catal. Sustain. Energy 2013, 1, 28-52. [CrossRef] 